\title{
Instagram User Experience in Learning Graphic Design
}

\author{
https://doi.org/10.3991/ijim.v14i11.13453 \\ Mohammad Salehudin $(\bowtie)$ \\ Institut Agama Islam Negeri Samarinda, Kalimantan Timur, Indonesia \\ salehudineiain-samarinda.ac.id \\ Abdulloh Hamid \\ Universitas Islam Negeri Sunan Ampel Surabaya, Surabaya, Indonesia \\ Zuhkhriyan Zakaria \\ Universitas Islam Malang, Malang, Indonesia \\ Widdy H.F Rorimpandey \\ Universitas Negeri Manado, Manado, Indonesia \\ Muhammad Yunus \\ Universitas Syiah Kuala Aceh, Banda, Aceh, Indonesia
}

\begin{abstract}
Mobile phone technology offers new opportunities to integrate face-to-face learning also other models of learning. Instagram is mostly only used for business and public figure exposure. But we see a tendency to use Instagram that students use in learning graphic design as a way to access content, publish work and learning outcomes using mobile phone. The purpose of this study is to find out the comparison of the average value of In-diagram assisted creative learning and measure the user experience (UX) of Instagram in learning graphic design. This study uses a quantitative approach with a pseudo experiment of non equivalent control group de-sign to find a comparison of the average value of student learning outcomes in the Statistical Test with MANOVA and to find out the average value of UX with UEQ Instagram benchmarks for learning graphic design. The results of the study there are significant differences (real) the average value between the experimental class group and the control class group. UX test results are on four scales that are categorized as ex-excellent, namely the scale of Attractiveness, efficiency, dependability, stimulation. One perspicuity scale is above average, and the novelty scale is good, the mean range is 1.33-2.00 according to the UEQ benchmark interval. The implication of this research is that Instagram through mobile phone technology is effectively used for the creative learning of graphic design lessons and needs to be developed as a medium for the development of teaching materials on all subject matter.
\end{abstract}

Keywords - User experience, Instagram social media, graphic design 


\section{Introduction}

The development of mobile phone technology in the 21st century is growing rapidly, indicated by all human activities at this time, no exception for education and learning which is known m-learning. Various uses of mobile phone technology for education and learning both at the school to college level, from novice students. [1] up to college student [2], the use of which includes uses for learning activities [3] used by the administrative staff [4] used to encourage the emergence of smart classes with efficient technology [5]. There is no gender difference in the use of mobile learning [6]. All of these uses are to overcome how students communicate and interact, also to overcome various obstacles in student learning problems, supported by different motivations and functions as a form of the development of current technological trends. The use of mobile technology holds various learning functions including seamless mobile learning [7], The popularity of Instagram as a social media used by millennials has grown day by day. The United States leads the ranking of countries with the most Instagram users with 110 million users as of April 2019, which uses Instagram to share and edit photos and short video. Brazil is second rank with 70 million Instagram users, India with an audience of 69 million users, while Indonesia is in fourth position with 59 million users. [8], So the use of Instagram has been widely used in the following fields: entertainment or games, sports, artists, business promotion interests or advertisements [9]; [10], medic [11], and so forth. Most parents have positive support for mobile technology [12], including pre-service teachers having positive opinions about mobile devices [6].

Social media in general can be used for learning [13] social media in cellular as a catalyst to trigger transformative curriculum design [14] great potential as a social learning platform [15] such as facebook [16] youtube [17]. Before the advent of Instagram there were three of the strongest social media, Facebook, Wikipedia, YouTube, used as learning resources [18]. But Instagram should also be used for learning. This is so potential because Instagram as a platform that is familiar with students, Instagram is very interested for young learner because this social media is more focused on photos and videos that have short duration compared to other social media that focus on long paragraphs, words or status in the narrative words. [19], Instagram has advantages in the independence of visual images, photos, and short videos with creative designs [20]; [21]; [22], share photo [23], There are many advantages to using Instagram, including the availability of interactive properties and the ability to be used anywhere, anytime according to our needs. Using mobile technology or cellular learning [24] So Instagram is very appropriate to be used as a medium or aid in the learning process because of the availability of all the supporting components.

Whereas graphic design produces the best visual works especially through computers, graphic design is related to advertisements and visual works [25] all visual results in this world are produced from graphic design work with creative and innovative ideas and imaginations. Instagram functions to distribute visual works, through the facility of Instagram graphic design works can be directly presented and published. Instagram is suitable or appropriate to be a medium used to learn graphic design. But the current problem is the use of Instagram in the learning process of graphic design subjects is still very limited because of the inadequate ability of teachers to develop and use 
Instagram so that an evaluation needs to be done [26] using the User Experience (UX) elements is very useful, because UX addresses the entire user experience [27] measurements through UX provide responses to design practitioners [28] measurement tools are available online using UEQ which has been used in assessing interactive media [29] has a benchmark and efficiency in quantitatively measuring the user experience of a product [30] The UEQ benchmark has six Attractiveness, Efficiency, Perspicuity, Dependability, Simulation and Novelty scales. By doing the UX evaluation, it is expected that intagram will be able to be used for learning specifically graphic design lessons, lessons that design visual design and the strength of visual communication design.

Interestingly Instagram for learning as described previously, based on evidence reported in the literature about the positive impact of Instagram for learning on academic achievement and student attitudes. This study tested the user experience of students in the basic subjects of graphic design tenth grade students majoring in multimedia. The main question that drives this research is, "does Instagram-aided creative learning improve student graphic design learning outcomes? How is UX Instagram on graphic design learning?"

\subsection{User Experience (UX)}

User Experience or commonly referred to as UX is a person's perception and response resulting from the use of the product, definition by UX design professionals [28], interactive products become a source of user experience [27]. More simply, User Experience is how you feel about each interaction you are facing with what lies ahead and when you use it. UX is dynamic, context dependent, and subjective [31] To get a good User Experience, a product must have a match between product features and user needs. This then determines the product is significant or valuable. Thus the influence of user experience is expected to help design products or services with a greater UX level [32]. And the last thing, the product must be easy to use to complete or do things the user wants. Find things done with a few questions with the UEQ tool [29].

\subsection{User Experience Questionnaire (UEQ)}

User Experience Questionnaire (UEQ) is a quantitative data processing tool (survey) related to user experience that is easily applied, trusted and valid, which can be used to supplement data from other evaluation methods with subjective quality assessments [30]. UEQ allows rapid assessment of the interactive product user experience. The questionnaire format supports user responses to immediately express feelings, impressions, and attitudes that arise when using a product. Attitudes toward measuring user experience are more positive than those identified in interviews, and there is a nuanced view of the measurement details [28].

The main purpose of the User Experience Questionnaire (UEQ) is to enable fasting and direct measurement of the interactive product user experience [33]. UEQ has been applied in various research contexts, for example for business software evaluation [29], user experience describes the user's subjective feelings for the product they are using. Different users or user groups may have different impressions about the user experience 
of the same product. So, measuring user experience usually requires gathering feedback from a larger group of users. This can be done most efficiently with questionnaires, especially if such a questionnaire is used as an online tool.

\subsection{Instagram as a social media}

Instagram is a web-based communication tool that allows people to interact with one another by sharing and consuming information [34]. Websites and applications dedicated to forums, microblogging, social networking, social bookmarking, social curation, and Wikipedia are among the various types of social media.

In short, social media is a site where anyone can create a personal webpage, then connect with friends to share information and communicate. The biggest social media right now are Facebook, Twitter, LinkedIn, Google+ and Instagram. If traditional media uses print and broadcast media, then social media uses the internet network [34]. Social media is used for education and learning [35], social media supports various communication functions as well as pedagogic functions [13].

\section{Method}

\subsection{Research design}

This research uses a quantitative approach using a quasi-experimental non equivalent control group design [36], This design involved a group that was given a pre-test $(\mathrm{O} 1)$, treatment $(\mathrm{X})$, and post-test $(\mathrm{O} 2)$. The success of Instagram-assisted graphic design learning is determined by comparing pre-test and post-test. In the pre-experimental study, one group pretest post-test, we carried out the first step by determining which samples would be used as samples and breaking them into one class research. The next stage is to provide a pre-test to measure learning outcomes before given graphic design learning assisted by Instagram. The next stage, the sample is given treatment using Instagram-assisted creative learning with mobile. Then, at the last stage, the sample is given a post-test to measure the results after which it is treated in the experimental and control groups. With the following designs:

Table 1. Experiment Implementation Procedures

\begin{tabular}{|l|c|c|c|c|c|c|c|c|}
\hline & \multicolumn{1}{|c|}{ Meeting } \\
\hline & $\mathbf{1}$ & $\mathbf{2}$ & $\mathbf{3}$ & $\mathbf{4}$ & $\mathbf{5}$ & $\mathbf{6}$ & $\mathbf{7}$ & $\boldsymbol{8}$ \\
\hline \multirow{2}{*}{ Class } & $\mathrm{O} 1$ & Experimentation Class & & $\mathrm{O} 2$ \\
\cline { 2 - 7 } & $\mathrm{O} 1$ & \multicolumn{1}{|l}{ Control class } & $\mathrm{O} 2$ \\
\hline
\end{tabular}

Explanation:

$\mathrm{O} 1=$ Pretest

$\mathrm{O} 2=$ Posttest

To supplement UX quantitative data, this study uses the online UEQ test (www.ueqonline.org) and open-ended questions related to the user experience of Instagram to learn graphic design. 


\subsection{Population and sample of the research}

The population taken was students in the tenth grade of information technology program multimedia studies in 2018/2019 as many as 144 students. The same retrieval technique is done by taking the entire population, considering there are only 144 students in four classes, two experimental classes and two control classes.

\subsection{Measurement of instrument}

The measurement scale of learning outcomes consisting of 12 items was used to achieve the objectives of this study. The item came from a review of questions about basic competencies, indicators and meeting materials. As for the application test the concept of using the description test totaling 12 questions, if a perfect answer is given a score of 8.3 if an imperfect answer is given a score of 4 and if no answer at all is given a score of 0 , so the highest score for the description problem is 8.3 and lowest 0 . Total urain score then multiplied by 12 so that the maximum score achieved is 100 and the lowest score 0 . Includes:

Table 2. Grid of item application concept questions

\begin{tabular}{|l|c|}
\hline \multicolumn{1}{|c|}{ Basic competencies } & Item Code \\
\hline Implement bitmap (raster) image processing software & 1,2 \\
\hline Using bitmap (raster) image processing software & 3,4 \\
\hline Implement raster image manipulation by using the effects feature & $5,6,12$ \\
\hline Manipulate raster images by using the effects feature & 8,9 \\
\hline Implement a bitmap (raster) based image design & 7,10 \\
\hline Create a bitmap (raster) based image design & 11 \\
\hline
\end{tabular}

For UX instruments we use the Indonesian version, because there are several language versions of the questionnaire that were built and validated (for example, English, Spanish, Portuguese and others). These versions are available free of charge at www.ueq-online.org. The reliability of the UEQ scale is usually high, that is, the Cronbach-Alpha coefficient is usually greater than 0.7 . The six elements or scales are translated into Indonesian as follows: Attractiveness, Clarity, Efficiency, Accuracy, Stimulation, and Novelty. UEQ contains 6 scales with a total of 26 items. namely: 
Table 3. Grid ítem about UX

\begin{tabular}{|l|l|l|l|}
\hline \multicolumn{1}{|c|}{ Scale } & \multicolumn{1}{c|}{ Item } & \multicolumn{1}{c|}{ Left } & \\
\hline Attraction & 6item & Annoying & Fun \\
\hline & & Good & Bad \\
\hline & & Dislike & Lovely \\
\hline & & Not Fun & Delightful \\
\hline & & Interesting & Not attractive \\
\hline & & Friendly & Not friendly \\
\hline & & Not understandable & Understandable \\
\hline & & Easy to Learn & Hard to Learn \\
\hline & & Difficult & Easy \\
\hline & & Vivid & Confusing \\
\hline & & Fast & Slow \\
\hline & & Not efficient & Efficient \\
\hline & & Not practical & Practical \\
\hline & & Well Organize & Messy \\
\hline Dependency & 4 item & Predictable & Unpredictable \\
\hline & & Obstructive & Support \\
\hline & & Safe & Not Safe \\
\hline & & Meet expectations & Do not meet expectations \\
\hline Stimulation & & Worth & Inferior \\
\hline & 4 item & Boring & Fascinate \\
\hline & & Not Interesting & Interesting \\
\hline & & Motivate & Unmotivated \\
\hline Novelty & Creative & Tiresome \\
\hline & & Inventive & Conventional \\
\hline & Oitem & Ordinary & Leading \\
\hline & & Conservative & Inovative \\
\hline & & &
\end{tabular}

\subsection{Data analysis}

This research is included in the quantitative study of the validity and reliability have been analyzed and analyzed by different experts. Data analysis was started using an independent sample t-test. To know the difference in the average value of student learning outcomes, between the experimental class and the control class, with a statistical significance value of 0.05 . Before the t-test was carried out, it had passed the normality test stage with the Ka Kolmogorov-Smirnov test and the data homogeneity test stage used the Levene Test quality test. Data analysis techniques in the study used MANOVA (Multivariate Analysis of Variance) with the help of the SPSS for Windows 24.0 program and all of the parametric assumptions above were carried out at a significance value of $5 \%$. The using of Manova test in order to involves several dependent variables [37] This research consists of two variables namely the learning outcomes of understanding concepts and application of concepts whereas moderator variables are high and low user experiences. 


\section{$3 \quad$ Result}

\subsection{Instagram-assisted creative learning of learning outcomes}

The mean score of the experimental group pretest learning outcomes is 70.82 with a standard deviation of 7.88 while the mean value of the pretest of the control group learning outcomes is 70.71 with a standard deviation of 7.88. The two are not different, meaning the two groups of subjects are homogeneous. Then after being given treatment the average value of the posttest experimental group learning outcomes was 84.39 with a standard deviation of 4.75 while the average value of the learning outcomes control group was 84.07 with a standard deviation of 4.26 .

Table 4. The results of the average value of pre-test and post-test

\begin{tabular}{|l|c|c|}
\hline & Mean & Standard Deviation \\
\hline Pre test Experiments & 70,82 & 7,88 \\
\hline Pre test Control & 70,71 & 7,88 \\
\hline Post test Exsperiments & 84,39 & 4,75 \\
\hline Post test Control & 84,07 & 4,26 \\
\hline
\end{tabular}

Hypothesis testing in this study was conducted using an independent sample t-test in order to determine the difference between the difference before and after treatment in each group, namely the experimental group and the control group.

Based on the test results the value of the Levene Test as presented in table 5, shows that the class is homogeneous. Therefore, the independent sample test results on the post test values of the experimental and control classes use the value in the first line (equal variances assumed) that is known to the value of Sig. Levene's Test for Equality of Variance is $0.474>0.05$, so it can be interpreted that the data variance between the experimental and control groups is homogeneous or the same. Furthermore, that the interpretation of the Independent Samples Test output table above is based on the values contained in the "equal variances assumed" table. Based on the Independent Samples Test output table in the equal variances assumed section, the Sig. (2-tailed) of 0,000 $<0.05$ then as the basis for decision making in the independent sample $t$ test, it can be concluded that $\mathrm{H} 0$ is rejected and $\mathrm{H} 1$ is accepted. Thus, it can be concluded that there is a significant difference (real) between the average student learning outcomes in the experimental group of creative learning assisted by social media Instagram and the group control model of problem-based learning.

Later on, as seen the p-value (Sign. 2-Tailed) in table 5, it is known that the P-Value (Sign. 2-Tailed) value is $0,000<0.05$. Therefore, the difference is significant at the probability of 0.05 . The magnitude of the difference in mean values as shown in the mean column of 3,944 means that the experimental group has an average value higher than the control group so that it can be concluded that the instagram-assisted creative learning applied to the experimental group is more effective than conventional learning applied to the group control seen from the acquisition of cognitive learning outcomes of students. 
Hereinafter the hypothesis is proven to be true and significant, high and low UX on learning outcomes is significantly 0,000 smaller than $<0.05$ as well as the results of learning interactions and UX on learning outcomes, significant results are 0,000 smaller than $<0.05$ can be seen in the results testing independent and dependent variables individually (Tests of Between-Subjects Effects Manova) MANOVA is presented in table 6.

Table 5. Results of Independent $T$ Test Samples Test

\begin{tabular}{|c|c|c|c|c|c|c|c|c|}
\hline \multicolumn{2}{|c|}{} & $\begin{array}{l}\text { Levene's Test for } \\
\text { Equality of Vari- } \\
\text { ances }\end{array}$ & \multicolumn{6}{|c|}{ t-test for Equality of Means } \\
\hline \multirow{3}{*}{ Post test } & $\boldsymbol{F}$ & Sig. & $\boldsymbol{t}$ & $\boldsymbol{d}$ df & $\begin{array}{c}\text { Sig. (2- } \\
\text { tailed) }\end{array}$ & $\begin{array}{c}\text { Mean Dif- } \\
\text { ference }\end{array}$ & $\begin{array}{c}\text { Std. Error } \\
\text { Difference }\end{array}$ \\
\hline & $\begin{array}{l}\text { Equal vari- } \\
\text { ances assumed }\end{array}$ & .514 & .474 & 5.064 & 142 & .000 & 3.944 & .779 \\
& $\begin{array}{l}\text { Equal vari- } \\
\text { ances not as- } \\
\text { sumed }\end{array}$ & & & 5.064 & 140.371 & .000 & 3.944 & .779 \\
\hline
\end{tabular}

Table 6. Test result between-subjects effects of MANOVA

\begin{tabular}{|c|c|c|c|c|c|c|}
\hline \multicolumn{7}{|c|}{ Tests of Between-Subjects Effects } \\
\hline Source & $\begin{array}{c}\text { Dependent } \\
\text { Variable }\end{array}$ & $\begin{array}{c}\text { Type III Sum of } \\
\text { Squares }\end{array}$ & $d f$ & Mean Square & $\boldsymbol{F}$ & Sig. \\
\hline \multirow{2}{*}{$\begin{array}{l}\text { Corrected } \\
\text { Model }\end{array}$} & Understanding & $3520.987 \mathrm{a}$ & 3 & 1173.662 & 59.990 & .000 \\
\hline & Application & $2562.370 \mathrm{~b}$ & 3 & 854.123 & 37.256 & .000 \\
\hline \multirow[t]{2}{*}{ Intercept } & Understanding & 1030178.107 & 1 & 1030178.107 & 52655.813 & .000 \\
\hline & Application & 1029706.097 & 1 & 1029706.097 & 44914.870 & .000 \\
\hline \multirow{2}{*}{ Learning } & Understanding & 253.356 & 1 & 253.356 & 12.950 & .000 \\
\hline & Application & 117.687 & 1 & 117.687 & 5.133 & .025 \\
\hline \multirow{2}{*}{ UX } & Understanding & 2794.302 & 1 & 2794.302 & 142.826 & .000 \\
\hline & Application & 1635.066 & 1 & 1635.066 & 71.320 & .000 \\
\hline \multirow{2}{*}{ Learning * UX } & Understanding & 214.929 & 1 & 214.929 & 10.986 & .001 \\
\hline & Application & 674.421 & 1 & 674.421 & 29.418 & .000 \\
\hline \multirow[t]{2}{*}{ Error } & Understanding & 2739.013 & 140 & 19.564 & & \\
\hline & Application & 3209.602 & 140 & 22.926 & & \\
\hline \multirow[t]{2}{*}{ Total } & Understanding & 1050744.000 & 144 & & & \\
\hline & Application & 1046512.000 & 144 & & & \\
\hline \multirow[t]{2}{*}{ Corrected Total } & Understanding & 6260.000 & 143 & & & \\
\hline & Application & 5771.972 & 143 & & & \\
\hline
\end{tabular}

a. R Squared $=, 562$ (Adjusted R Squared $=, 553$ )

b. $\mathrm{R}$ Squared $=, 444$ (Adjusted R Squared $=, 432)$

\subsection{User experience on instagram to learn graphic design}

Instagram as a media of learning and publishing a work and design results, it is made clear in the findings of this study, that there is an average value of six UX items (attractiveness, perspicuity, efficiency, dependability, stimulation, and novelty) that have been 
tested with UEQ Online, with The benchmarks found four items with Excellent, one item with Above Average and one with Good benchmark. UX research results can be seen in the color code according to the group and instrument items on the right and left points. The results can be seen in table 7:

Table 7. The value of the results of the UX respondents' answers

\begin{tabular}{|c|c|c|c|c|c|c|}
\hline Item & Mean & Variance & Std. Dev. & Left & Right & Scale \\
\hline 1 & 1,4 & 1,9 & 1,4 & Annoying & Enjoyable & Attractiveness \\
\hline 2 & 0,9 & 2,4 & 1,5 & Not understandable & Understandable & Perspicuity \\
\hline 3 & 2,1 & 0,9 & 0,9 & Creative & Dull & Novelty \\
\hline 4 & 2,3 & 1,1 & 1,1 & Easy to learn & Difficult to learn & Perspicuity \\
\hline 5 & 2,1 & 0,8 & 0,9 & Valuable & Inferior & Stimulation \\
\hline 6 & 1,9 & 1,7 & 1,3 & Boring & Exciting & Stimulation \\
\hline 7 & 1,4 & 2,1 & 1,4 & Not interesting & Interesting & Stimulation \\
\hline 8 & 1,1 & 2,5 & 1,6 & Unpredictable & Predictable & Dependability \\
\hline 9 & 2,2 & 1,4 & 1,2 & Fast & Slow & Efficiency \\
\hline 10 & 1,3 & 1,7 & 1,3 & Inventive & Conventional & Novelty \\
\hline 11 & 1,5 & 2,3 & 1,5 & Obstructive & Supportive & Dependability \\
\hline 12 & 2,2 & 1,1 & 1,0 & Good & $\mathrm{Bad}$ & Attractiveness \\
\hline 13 & 0,7 & 2,8 & 1,7 & Complicated & Easy & Perspicuity \\
\hline 14 & 2,0 & 1,0 & 1,0 & Unlikable & Pleasing & Attractiveness \\
\hline 15 & 0,5 & 1,7 & 1,3 & Usual & Leading edge & Novelty \\
\hline 16 & 1,4 & 1,9 & 1,4 & Unpleasant & Pleasant & Attractiveness \\
\hline 17 & 2,3 & 0,9 & 1,0 & Secure & Not secure & Dependability \\
\hline 18 & 2,3 & 0,9 & 1,0 & Motivating & Demotivating & Stimulation \\
\hline 19 & 2,1 & 1,1 & 1,0 & Meets expectations & $\begin{array}{l}\text { Does not meet ex- } \\
\text { pectations }\end{array}$ & Dependability \\
\hline 20 & 1,8 & 1,2 & 1,1 & Inefficient & Efficient & Efficiency \\
\hline 21 & 2,2 & 1,4 & 1,2 & Clear & Confusing & Perspicuity \\
\hline 22 & 2,0 & 0,9 & 1,0 & Impractical & Practical & Efficiency \\
\hline 23 & 2,0 & 0,5 & 0,7 & Organized & Cluttered & Efficiency \\
\hline 24 & 2,0 & 0,9 & 1,0 & Attractive & Unattractive & Attractiveness \\
\hline 25 & 1,8 & 1,2 & 1,1 & Friendly & Unfriendly & Attractiveness \\
\hline 26 & 1,4 & 3,1 & 1,7 & Conservative & Innovative & Novelty \\
\hline
\end{tabular}

Then, we found UX Instagram on four scales that were categorized as excellent, namely the Attractiveness, Efficiency, Dependability and Stimulation scales, while the Perspicuity scale was categorized as Above Average and Novelty categorized as Good according to the benchmark interval set by UEQ. The following knows the benchmarks of the calculation results at UEQ can be seen in Figure 1. 


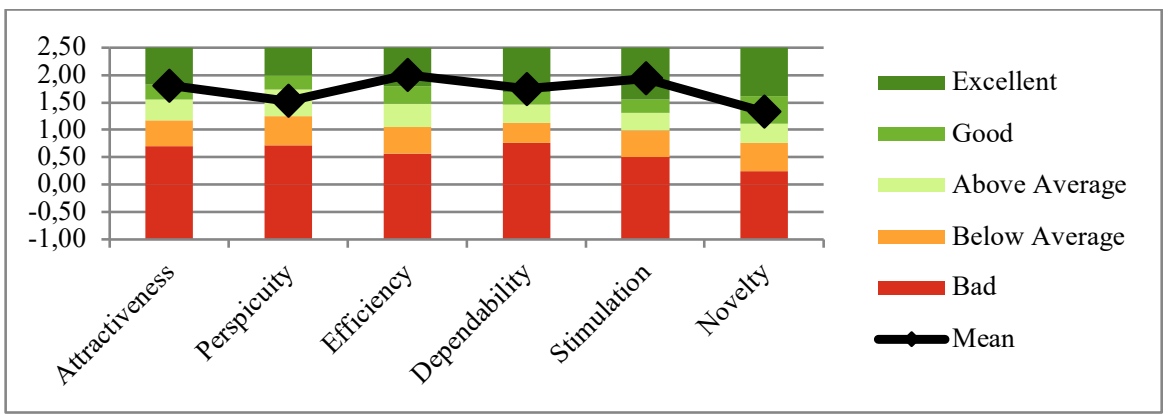

Fig. 1. Results on UEQ Benchmarks

Hereafter, our findings with an average impression value between -0.8 and 0.8 are normal evaluation values, values $>0.8$ are positive evaluations and values $<-0.8$ are negative evaluations. So, it can be concluded that the application of instragram as a media for learning graphic design, a place for publication and displaying student work tends to have positive impressions (values are in the direction of 1 and above) successively decreasing in the group efficiency, attractiveness, dependability, perspiculty, stimulation and novelty.

Table 8. UEQ Benchmark - Average Value for each Factor

\begin{tabular}{|l|c|c|c|c|c|c|c|}
\hline \multicolumn{7}{|c|}{ Table to create the benchmark graph (purely technical, please ignore) } \\
\hline & $\begin{array}{c}\text { Lower } \\
\text { Border }\end{array}$ & Bad & $\begin{array}{c}\text { Below } \\
\text { Average }\end{array}$ & $\begin{array}{c}\text { Above } \\
\text { Average }\end{array}$ & Good & Excellent & Mean \\
\hline Attractiveness & $-1,00$ & 0,7 & 0,47 & 0,39 & 0,27 & 0,67 & 1,81 \\
\hline Perspicuity & $-1,00$ & 0,71 & 0,54 & 0,48 & 0,27 & 0,5 & 1,53 \\
\hline Efficiency & $-1,00$ & 0,57 & 0,48 & 0,43 & 0,32 & 0,7 & 2,00 \\
\hline Dependability & $-1,00$ & 0,77 & 0,36 & 0,33 & 0,23 & 0,81 & 1,75 \\
\hline Stimulation & $-1,00$ & 0,5 & 0,49 & 0,32 & 0,24 & 0,95 & 1,94 \\
\hline Novelty & $-1,00$ & 0,25 & 0,52 & 0,35 & 0,49 & 0,89 & 1,33 \\
\hline
\end{tabular}

The results on the Attractiveness scale finding have an average value of 1.81 in the Excellent position with an interpretation of $10 \%$ better results, $75 \%$ worse results, on the Perspicuity scale there is an average value of 1.53 Above Average positions with an interpretation of $25 \%$ better results , $50 \%$ worse results, on the Efficiency scale there is an average value of 2.00 Excellent positions with interpretation in the range of $10 \%$ best results, On the Dependability scale there is an average value of 1.75 Excellent positions with interpretations in the range of $10 \%$ best results, At Stimulation scale, there is an average value of 1.94 Excellent positions with an interpretation in the range of $10 \%$ of the best results, on the Novelty scale there are results of an average value of 1.33 Good positions with an interpretation of $10 \%$ better results, $75 \%$ worse results. 


\section{Discussion}

\subsection{The cause of the high comparison of the average value of creative learning aided by graphic design learning lessons}

The findings of this study showed that the average student learning outcomes in the experimental class using Instagram-assisted learning was higher than the control class using Instagram-assisted learning control in graphic design subjects. Hypothesis test results using the Independent Sample Test there are high differences, H0 rejected and $\mathrm{H} 1$ accepted or there were significant differences from the two experimental class groups and the control class.

There are several factors causing the achievement of high learning outcomes, First, Instagram as a social media is liked by students and easy to use, besides that Instagram is trying to integrate it into a new power of m-learning [38], supporting Al-Ali's (2014) research which found the use of Instagram to learn languages shows that students' initiatives were not enthusiastic at first, but students gradually completed writing activities, they welcomed the idea and were encouraged to be creative [38]. Second, student addiction to social media [39], easy to operate, graphic design on instagram can develop comfortably and pleasantly so that it affects the value of students' learning outcomes in the cognitive application [40]. Third, Graphic design lessons are incorporating the field of cognitive science into instructional technology so that the effectiveness of graphic design using Instagram can be optimized [41] Fourth, learning used in achieving high learning outcomes uses creative learning strategies, where creative learning guides daily lessons with the aim of gaining deep-rooted knowledge through creative processes while solving standards-based problems. Through this work we aim to expand the reach of analytic learning into serious games [42-45]. Creative solutions are associated with knowledge that was previously known / remembered, identified, newly acquired, applied before, newly applied, practiced, planned, compared, contrasted, made/produced, assessed/evaluated, presented and remade [46]. Fifth, Through creative learning assisted by social media especially Instagram [47] students can explore their imagination, creativity, skills, grow their potential for learning, as motivation and present their work of graphic design in a comfortable and enjoyable way.

\subsection{User experience on instagram for learning graphic design}

Instagram for learn graphic design using the @kuliahdesign2019 account as the main account of teachers and students. Through this instagram students can start lessons and complete learning tasks in Instagram form, students look for material and find ideas and ideas through hashtags (\#) on Instagram. Then on Instagram students can directly publish their Instagram work on their account or use the specified hashtag, for example \# officialmm1 1mm2, \# ximm1 account. 

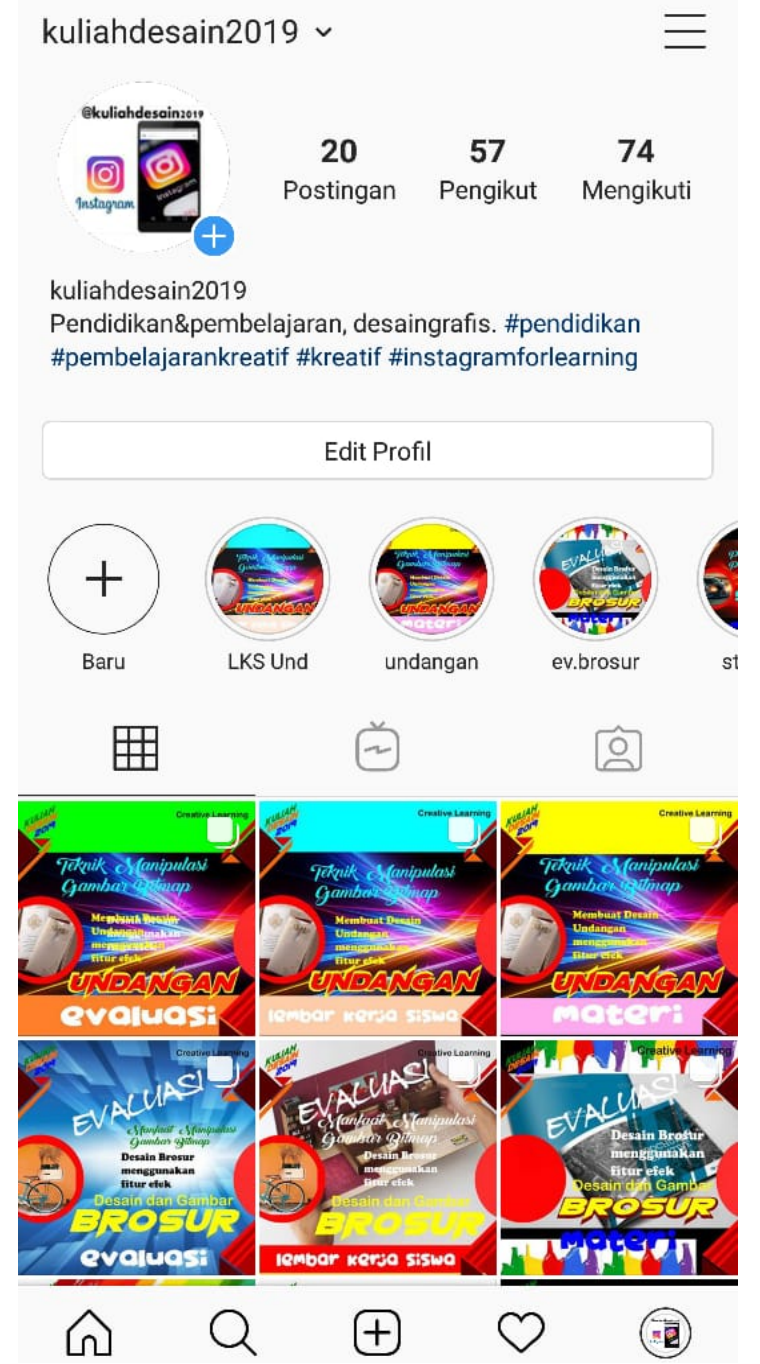

Fig. 2. Instagram display @ kuliahdesign2019 in learning graphic design

The findings from the UEQ test results with six scales, instagram user experience in learning graphic design with Instagram results on the scale of Attractiveness, Efficiency, Dependability and Stimulation are in an Excellent position, students feel the learning fun, not bored and bored. As well as on the Perspicuity scale Above Average position, on the Novelty scale Good position in learning graphic design students discover many new things, students find ideas and ideas quickly and enrich design insights, Instagram has a hashtag (\#) that is full of visual power that can stimulate the imagination and the creativity potential of students in creating.

Based on Kolokytha [48] the use of Instagram to learn graphic design is very helpful for students, where this lesson requires the power of imagination. Weakness of 
imagination becomes an obstacle in graphic design lessons; students' imagination in working with all the potential psychological power to process their cognitive potential makes good and creative work. Instagram makes graphic design work easy, given that graphic design is heavy and difficult, many aspects affect the design, perception aspects, alignment detection aspects, and hierarchical segmentation [49]. Through Instagram students find many ideas, design patterns and how students work as beginners sometimes have problems in starting designs and finding ideas. So using Instagram students is very helpful in finding design ideas, including in assessing the design [50] communication constraints of students and teachers in learning can be overcome by the use of social media [51], students can learn anywhere and anytime to hone their cognitive skills and knowledge towards high learning outcomes [25].

Instagram for learning graphic design from the side of "clarity", and "novelty" can be said that it is a new discovery in learning graphic design, has a novelty for creative learning graphic design for high school students. Instagram helps students discover new things and find imagination to work on and do design work. Furthermore, for any lesson, if it requires the power of imagination, ideas and ideas of students, then Instagram can be used in lessons because Instagram is liked by students and has the power to attract and eliminate boredom in learning. Furthermore, if all this time the teaching material has only been adhered to in books and manuals, then through Instagram the teaching material provided a solution as a digital teaching material, interesting and enjoyable for students meaning that any learning can use Instagram as from the findings of this study. This Instagram research directs behavior through mobile phonetechnology (mobile learning) in an effective way to be used for creative learning of graphic design lessons and needs to be developed into a medium for teaching material development on all subject matter, instagram can be used as an alternative and adoption becomes e-learning in future research.

\section{Conclusion}

Instagram-assisted learning has high average learning outcomes, the effect of Instagram and UX-assisted creative learning on the learning outcomes of learning and application concepts is with significant results and categories. Instagram in the experimental class uses Instagram as well as control. Then it can be concluded that learning with Instagram will have a real and significant influence on student learning outcomes. Then for UEQ test results on UX Instagram analysis to learn graphic design found in the position above Good to Excellent position shows Instagram is a good tool to explore the imagination, ideas and productivity of students in learning graphic design that requires strength and wealth of imagination in order to have quality results design work. An important finding is on the teacher's role to innovate the learning process, the teacher guides and becomes a facilitator on creative learning to make learning more creative, enjoyable, based on student experience, experiments, presentations, and inspires all students.

This study recommends that graphic design teachers and further research add additional internal factors such as student and external characteristics such as school 
curriculum support, school regulations regarding the provisions of carrying a smartphone, adequate internet availability, educational background, family, and so on. It needs to be done as a part that can be utilized in effective, efficient and attractive learning.

\section{References}

[1] J. Masters, "Creative Teaching and Learning Strategies for Novice Users of Mobile Technologies," Int. J. Mob. Blended Learn., vol. 5, no. (3), pp. 68-79, 2013. https:// doi.org/10.4018/jmbl.2013070105

[2] M. Rojas-osorio and A. Alvarez-risco, "Intention to Use Smartphones among Peruvian University Students," Int. J. Interact. Mob. Technol., vol. 13, no. 3, pp. 40-52, 2019. https://doi.org/10.3991/ijim.v13i03.9356

[3] I. Lestari, A. Maksum, and C. Kustandi, "Mobile Learning Design Models for State University of Jakarta, Indonesia,” Int. J. Interact. Mob. Technol., vol. 13, no. 9, pp. 152-171, 2019. https://doi.org/10.3991/ijim.v13i09.10987

[4] H. M. Al Fawareh and S. Jusoh, "The Use and Effects of Smartphones in Higher Education," Int. J. Interact. Mob. Technol., vol. 11, no. 6, pp. 103-111, 2017.

[5] A. Al-hunaiyyan, S. Al-Sharhan, and R. Alhajri, "A New Mobile Learning Model in the Context of Smart Classroom Environment: A Holistic Approach," Int. J. Interact. Mob. Technol., vol. 11, no. 3, pp. 39-56, 2017. https://doi.org/10.3991/ijim.v11i3.6186

[6] S. Papadakis, "Evaluating pre-service teachers' acceptance of mobile devic-es with regards to their age and gender: A case study in Greece," Int. J. Mob. Learn. Organ., vol. 12, no. 4, pp. 336-352, 2018. https://doi.org/10.1504/ijmlo.2018.10013372

[7] A. Hamid, P. Setyosari, D. Kuswandi, and S. Ulfa, "The Implementation of Mobile Seamless Learning Strategy in Mastering Students' Concepts for Elemen-tary School,” J. Educ. Gift. Young Sci., vol. 7, no. 4, pp. 967-982, 2019. https://doi.org/10.17478/jegys. $\underline{622416}$

[8] Statista, Leading countries based on number of Instagram users as of July 2019 (in millions), July. 2019.

[9] K. D. Mukhina, S. V Rakitin, A. A. Visheratin, D. Mukhina, V. Rakitin, and A. Visheratin, "ScienceDirect Detection of tourists attraction points using profiles points Detection tourists Detection of of Instagram tourist's attraction attraction points using using Instagram profiles profiles Instagram Introduction," Procedia Comput. Sci., vol. 108, no. June, pp. 2378-2382, 2017. https://doi.org/10.1016/j.procs.2017.05.131

[10] M. AbdelFattah, D. Galal, N. Hassan, D. S. Elzanfaly, and G. Tallent, "A Sentiment Analysis Tool for Determining the Promotional Success of Fashion Im-ages on Instagram,” Int. J. Interact. Mob. Technol., vol. 11, no. 2, pp. 66-73, 2017. https://doi.org/10.3991/ijim. $\underline{\mathrm{v} 11 \mathrm{i} 2.6563}$

[11] F. M. Hindman, A. E. Bukowitz, B. N. Reed, and T. J. Mattingly, "No filter: A characterization of \#pharmacist posts on Instagram," J. Am. Pharm. Assoc., vol. 57, no. 3, pp. 318 325, 2017. https://doi.org/10.1016/j.japh.2017.01.009

[12] S. Papadakis, N. Zaranis, and M. Kalogiannakis, "Parental involvement and attitudes towards young Greek children's mobile usage," Int. J. Child-Computer In-teract., vol. 22, p. 100144, 2019. https://doi.org/10.1016/j.ijcci.2019.100144

[13] J. Osgerby and D. Rush, "An exploratory case study examining undergradu-ate accounting students' perceptions of using Twitter as a learning support tool," Int. J. Manag. Educ., vol. 13, no. 3, pp. 337-348, 2015. https://doi.org/10.1016/j.ijme.2015.10.002 
[14] T. Cochrane and L. Antonczak, "Connecting the theory and practice of mo-bile learning: a framework for creative pedagogies using mobile social media," MEDIA Educ. - Stud. Ric. buone Prat., vol. 6, no. 2, pp. 248-269, 2015.

[15] K. F. Hashim, A. Rashid, and S. Atalla, "Social Media for Teaching and Learning within Higher Education Institution: A Bibliometric Analysis of the Lit-erature (2008-2018), Int. J. Interact. Mob. Technol., vol. 12, no. 7, pp. 4-19, 2018. https://doi.org/10.3991/ijim. v12i7.9634

[16] A. Varol and R. Dhyab, "Distance Education Features using Facebook," Int. J. Interact. Mob. Technol., vol. 12, no. 6, pp. 19-34, 2018. https://doi.org/10.3991/ijim.v12i6.9621

[17] S. Moghavvemi, A. Sulaiman, N. I. Jaafar, and N. Kasem, "Social media as a complementary learning tool for teaching and learning: The case of youtube," Int. J. Manag. Educ., vol. 16, no. 1, pp. 37-42, 2018. https://doi.org/10.1016/j.ijme.2017.12.001

[18] Y. Liu, "Social Media Tools as a Learning Resource," J. Educ. Technol. Dev. Exch., vol. 3, no. 1, pp. 101-114, 2010.

[19] R. A. Manampiring, "Peranan Media Sosial Instagram Dalam Interaksi So-sial Antar Siswa SMA Negeri I Manado (Studi pada Jurusan IPA Angkatan 2012)," e-journal “Acta Diurna," vol. IV, no. 4, 2015.

[20] D. S. Hunt, C. A. Lin, and D. J. Atkin, "Communicating Social Relationships via the Use of Photo-Messaging,” J. Broadcast. Electron. Media, vol. 58, no. 2, pp. 234-252, 2014. https://doi.org/10.1080/08838151.2014.906430

[21] L. Manovich, "Subjects and Styles in Instagram Photography (Part 2), In-stagram Contemp. Image, no. Part 2, pp. 1-20, 2016.

[22] A. Shaw, design for motion motion design Techniques and Fundamentals, vol. 8645, no. 773. New York London: Taylor \& Francis, 2016.

[23] C. S. Lee, N. Alifah, and B. Abu, "Instagram This! Sharing Photos on Insta-gram," Springer Int. Publ. Switz., pp. 132-133, 2015.

[24] J. Pachler, N., Bachmair, B. \& Cook, Mobile learning: structures, agency, practices. New York: Springer, 2010.

[25] H. S. and H. H. K. Stuart, "Advertising Graphic Design and Its Effect on Re-call and Attitude: A Field Experiment," 1974.

[26] V. Mittal, A. Kaul, S. Sen Gupta, and A. Arora, "Multivariate Features Based Instagram Post Analysis to Enrich User Experience,” Procedia Comput. Sci., vol. 122, pp. 138-145, 2017. https://doi.org/10.1016/j.procs.2017.11.352

[27] F. Pucillo, G. Cascini, P. Milano, V. Giuseppe, and L. Masa, “A framework for user experience, needs and affordances," Des. Stud., vol. 35, no. 2, pp. 160-179, 2014. https://doi. org/10.1016/j.destud.2013.10.001

[28] E. L. Law, P. Van Schaik, and V. Roto, "Attitudes towards User Experience (UX) Measurement,” J. Human-Computer Stud., vol. 72, no. 6, pp. 526-541, 2014. https://doi.org/ 10.1016/j.ijhcs.2013.09.006

[29] M. Schrepp, A. Hinderks, and J. Thomaschewski, “Applying the User Experi-ence Questionnaire (UEQ) in different evaluation scenarios Construction of the User Experience Questionnaire (UEQ)," in International Conference of Design, User Experience, and Usability, 2014, pp. 383-392. https://doi.org/10.1007/978-3-319-07668-3_37

[30] M. Schrepp, A. Hinderks, and J. Thomaschewski, "Construction of a Benchmark for the User Experience Questionnaire (UEQ)," Int. J. Interact. Mul-timed. Artif. Intell., vol. 4, no. 4, pp. 40-44, 2017. https://doi.org/10.9781/ijimai.2017.445

[31] E. L.-C. Law, V. Roto, M. Hassenzahl, A. P. O. S. Vermeeren, and J. Kort, "Understanding, Scoping and Defining User eXperience: A Survey Approach," in Proceedings of the 27th 
International Conference on Human Factors in Compu-ting Systems - CHI, 2009, pp. 719 728. https://doi.org/10.1145/1518701.1518813

[32] J. Park, S. H. Han, H. K. Kim, Y. Cho, and W. Park, "Developing Elements of User Experience for Mobile Phones and Services: Survey, Interview, and Obser-vation Approaches," Hum. Factors Ergon. Manuf. Serv. Ind., vol. 23, no. 4, pp. 279-293, 2011. https://doi.org/ $\underline{10.1002 / \mathrm{hfm} .20316}$

[33] M. Schrepp, "User Experience Questionnaire Handbook," no. September, 2015.

[34] J. Berger and J. Berger, "Beyond Viral: Interpersonal Communication in the Internet Age Beyond Viral: Interpersonal Communication in the Internet Age," Psychol. Inq. An Int. J. Adv. Psychol. Theory, vol. 24, no. 4, pp. 293-296, 2013. https://doi.org/10.1080/1047 $\underline{\text { 840x.2013.842203 }}$

[35] S. A. Alabdulkareem, "Exploring the Use and the Impacts of Social Media on Teaching and Learning Science in Saudi," Procedia - Soc. Behav. Sci., vol. 182, pp. 213-224, 2015. https://doi.org/10.1016/j.sbspro.2015.04.758

[36] J. W. Creswell, Research Design: Qualitative, Quantitative and Mixed Meth-ods Approaches, Fourth Edi. California: SAGE Publications, Inc., 2014.

[37] H. Latan, Aplikasi Analisis Data Statistik Untuk Ilmu Sosial Sains dengan IBM SPSS. Bandung: Alfabeta, CV, 2014.

[38] S. Al-ali, "Embracing the selfie craze: exploring the possible use of instagram as a language mlearning tool," Issues Trends Educ. Technol., vol. 2, no. 2, pp. 1-16, 2014. https://doi.org/10.2458/azu itet v2i2 ai-ali

[39] C. Şahin, "Social Media Addiction Scale - Student Form: The Reliability and Validity Study,” TOJET Turkish Online J. Educ. Technol., vol. 17, no. 1, pp. 169-182, 2018.

[40] D. R. Krathwohl, “A Revision of Bloom' s Taxonomy: An Overview,” Krat. D. R. (2002). A Revis. Bloom's Taxon. An Overv. (Vol. 41)., vol. 41, no. 4, 2002.

[41] L.-J. ChanLin, "A Theoretical analysis of Learning with Graphics - Implica-tions for Computer Graphics Design,” Eric, pp. 1-22.

[42] N. Vidakis, A. K. Barianos, A. M. Trampas, S. Papadakis, M. Kalogiannakis, and K. Vassilakis, "Generating education in-game data: The case of an ancient theatre serious game," CSEDU 2019 - Proc. 11th Int. Conf. Comput. Support. Educ., vol. 1, no. Csedu, pp. 36-43, 2019. https://doi.org/10.5220/0007810800360043

[43] S. Papadakis, and V. Orfanakis, "The combined use of Lego Mindstorms NXT and App Inventor for teaching novice programmers". In International Con-ference EduRobotics 2016 (pp. 193-204). Springer, Cham, 2016. https://doi.org/10.1007/978-3-319-55553-9 15

[44] S. Papadakis, and M. Kalogiannakis, "Using gamification for supporting an introductory programming course. the case of classcraft in a secondary education classroom". In Interactivity, Game Creation, Design, Learning, and Innovation (pp. 366-375). Springer, Cham, 2016. https://doi.org/10.1007/978-3-319-76908-0_35

[45] S. Papadakis, and V. Orfanakis, "Comparing novice programing environ-ments for use in secondary education: App Inventor for Android vs. Alice”. Inter-national Journal of Technology Enhanced Learning, 10(1-2), 44-72, 2018. https://doi.org/10.1504/ijtel.2018.1000 $\underline{8587}$

[46] V. A. Ellis, "Introducing the Creative Learning Principles: Instructional Tasks Used to Promote Rhizomatic Learning Through Creativity," Clear. House A J. Educ. Strateg. Issues Ideas, vol. 89, no. July 4-5, pp. 125-134, 2016. https://doi.org/10.1080/00098655. $\underline{2016.1170448}$

[47] M. Salehudin, N. S. Degeng, Sulthoni, and S. Ulfa, "The influence of creative learning assisted by instagram to improve middle school students' learning out-comes of graphic design 
subject,” J. Educ. Gift. Young Sci., vol. 7, no. 4, pp. 849-866, 2019. https://doi.org/ 10.17478/jegys.626513

[48] E. Kolokytha, S. Loutrouki, S. Valsamidis, and G. Florou, "Social Media Networks as a Learning Tool," Procedia Econ. Financ., vol. 19, no. 15, pp. 287-295, 2015. https://doi. org/10.1016/s2212-5671(15)00029-5

[49] P. O. Donovan, A. Agarwala, A. Hertzmann, and S. Member, "Learning Layouts for SinglePage Graphic Designs,” IEEE Trans. Vis. Comput. Graph., vol. 20, no. 8, pp. 1200-1213, 2014. https://doi.org/10.1109/tvcg. 2014.48

[50] G. Ellmers and S. Bennett, "Graphic Design Education: A Revised Assess-ment Approach to Encourage Deep Learning Graphic Design,” J. Univer sity Teach. Learn. Pract., vol. 5, no. 1, pp. 1-11, 2008.

[51] K. Usher et al., "Australian Health Professions Student Use of Social Media," Collegian, vol. 21, no. 2, pp. 95-101, 2014.

\section{$7 \quad$ Authors}

Mohammad Salehudin is a Doctor of learning technology at IAIN Samarinda in Indonesia. His research interests are educational technology, learning technology, social media, distance education, LMS, etc. Worked as a Media and Technology Education lecturer at IAIN Samarinda, East Kalimantan, Indonesia.

Abdulloh Hamid is a Doctor of learning technology. He completed his master's degree in Educational and Vocational Technology State University of Yogyakarta in 2013, worked as a lecturer Educational Technology in Universitas Islam Negeri Sunan Ampel State Islamic University Surabaya. He is interested in researches focused on Mobile Seamless Learning, Digital Literacy, Educational Technology, Islamic Media, Moslem Moderate, Pesantren Studies and Islamic Studies.Email: doelhamid@uinsby.ac.id

Zuhkhriyan Zakaria is a Doctor of educational technology. He has been active in the art world since 2005 as a visual and performance art artist. Worked as a lecturer in art education at the Islamic Elementary School Teacher Education Faculty of Islamic Studies, Universitas Islam Malang. His research interests are art educational technology, performance art, digital literacy, art learning, etc. zakaria@unisma.ac.id

Widdy H.F Rorimpandey is a Doctor of learning technology and lecturer of Primary Teacher Education Department, Universitas Negeri Manado, Indonesia, his research includes Teaching Science Education as Primary Teacher Education (PGSD), and Teaching Learning Strategy, Teaching Science for Candidate Teacher. Email: widdyrorimpandey@unima.ac.id

Muhammmad Yunus is a lecturer at Universitas Syiah Kuala University, AcehIndonesia. Teaching in the field of learning, the focus is on planning courses, strategies and learning media. Currently continuing Doctoral Education in the field of Educational technology at the State University of Malang, Indonesia. And the focus of research that is being cultivated in online-based learning. Email: yunus.msalem@unsyiah.ac.id

Article submitted 2020-01-28. Resubmitted 2020-04-06. Final acceptance 2020-04-06. Final version published as submitted by the authors. 